\title{
DESIGN OF EXPERIMENTS IN THE STUDY OF BAUXITE REFRACTORY CASTABLE PROPERTIES
}

\author{
"ILONA KIELIBA*, JACEK PODWÓRNY**, JACEK SZCZERBA* \\ *AGH University of Science and Technology, Faculty of Materials Science and Ceramics, \\ al. A. Mickiewicza 30, 30-059 Kraków, Poland \\ **Institute of Ceramics and Building Materials, Refractory Materials Division in Gliwice, Poland \\ ${ }^{\#}$ E-mail: ikieliba@agh.edu.pl
}

Submitted January 23, 2017; accepted March 9, 2017

Keywords: Plackett-Burman experimental design, bauxite, low-cement refractory castables

\begin{abstract}
This paper presents results of an investigation of the influence of preparation conditions of low-cement refractory castables on their service properties using experiment planning methods. Using the orthogonal Plackett-Burman design, the influence of the amount of water, vibration time, curing conditions and firing conditions on the service properties of the finished refractory castable (apparent density, open porosity, permanent linear changes, Young's modulus, bending strength and compressive strength at ambient temperature) is demonstrated. It is found that, among the investigated properties under the conditions of the conducted experiment, only the mixing time is a negligible factor that has no significant influence on the process of developing service properties of low-cement bauxite castables.
\end{abstract}

\section{INTRODUCTION}

The consumption of unshaped refractory materials is steadily increasing. This increase is connected with the constantly expanding range of applications of refractory castables and the rapid development of new technologies ensuring their high quality [1-3]. It is estimated that the volume of production of monolithic materials in EU countries accounts for approx. $40 \%$ of all produced refractory materials.

Owing to a number of advantages offered by these materials, which are achieved by the reduction of the quantity of cement used and the introduction of nanoand micro-additives as well as appropriate liquefiers, low-cement bauxite refractory castables find application in many industries, such as the power, petrochemical and chemical industries.

The proper installation and heating up of refractory linings to match the operation conditions of a thermal installation are among the key factors that determine their service life [3-4]. Achieving the expected properties of refractory linings is only possible if the installation work is conducted under strictly defined conditions. Any deviations from the manufacturer's recommendations that might take place in industrial practice, resulting from the wish to reduce the installation operation time, affects the physical and chemical processes occurring in the material, which in turn has an influence on the obtained final properties of the castable refractory lining, and thus on its durability.
The existing literature shows a lack in data on the influence of deviations occurring from the design specifications or the manufacturer's recommendations on the properties of the finished refractory castable. In view of the above, this study focuses on the determination of the relationships between the preparation conditions and the service properties of bauxite castables.

Work on design of experiment was initiated by Sir Roland Fisher in the 1920s [6] and developed in the 1930s [7], but, in spite of the unquestionable benefits of the results of that work, its use in research has not become common practice to the present day. Nevertheless, in the last few years there is a trend towards the use of design of experimentnot only in natural sciences [8] but also in studies of ceramic [9-11], metallic and polymeric materials [12].

It is clear that the common practice of conducting tests by the single-factor method, consisting in changing only one parameter, with the others remaining unchanged, is highly ineffective in cases where many factors have to be examined. It involves a large number of experiments to be carried out, which will yield an excessive number of results, whose interpretation will be difficult [13-14].

Examining many factors at the same time is possible if appropriate experiment designs are used.

The orthogonal Plackett-Burman design [15] belongs to the group of selective factor designs that enable the examination of a larger number of factors simultaneously, the determination of the significance of their influence on individual properties and the selection of significant 
factors for subsequent model or optimization studies. The outcome of the Plackett-Burman experiment does not specify a relationship between the variable and the result; however, it does enable a possible influence, or its lack, on the examined function to be shown.

The aim of the present study was to determine, using experiment planning methods, the relationship between the conditions of making and firing low-cement bauxite castables and their service properties, and to select variables that significantly influence the process of developing the properties under investigation, i.e. the apparent density, open porosity, permanent linear changes, as well as Young's modulus, compressive strength and bending strength at ambient temperature.

\section{EXPERIMENTAL}

Test material

A commercially available low-cement bauxite castable mix was used for testing. The physical properties of the castable after firing at $800^{\circ} \mathrm{C}$, as declared by the manufacturer, are as follows: apparent density $2.82 \mathrm{~g} \cdot \mathrm{cm}^{-3}$, compressive strength $100 \mathrm{~N} \cdot \mathrm{mm}^{-2}$, permanent linear changes $-0.30 \%$ and open porosity $22 \%$. The chemical and phase composition of the commercial bauxite castable mix used in this study is summarized in Table 1.

For the purpose of carrying out the experiments, eight types of $230 \times 64 \times 64 \mathrm{~mm}$ samples were made. Variable conditions of castable mix preparation, curing

Table 1. Chemical and phase composition of the tested bauxite castable mix (producer's data).

\begin{tabular}{lcc}
\hline \multicolumn{2}{c}{ Chemical composition } & $\begin{array}{c}\text { Phase composition of } \\
\text { castable mix }\end{array}$ \\
\hline Oxide & Declared content & $\alpha-\mathrm{A}, \beta-\mathrm{A}, \mathrm{A}_{3} \mathrm{~S}_{2}, \mathrm{AS}$, \\
$\mathrm{Al}_{2} \mathrm{O}_{3}$ & $84 \%$ & $\mathrm{CA}, \mathrm{CA}_{2}, \mathrm{C}_{12} \mathrm{~A}_{17}, \mathrm{TA}^{*}$ \\
$\mathrm{SiO}_{2}$ & $8 \%$ & Amorphous phase \\
$\mathrm{CaO}$ & $2.3 \%$ & \\
$\mathrm{P}_{2} \mathrm{O}_{5}$ & $1 \%$ & \\
$* A \equiv \mathrm{Al}_{2} \mathrm{O}_{3}, \mathrm{~S} \equiv \mathrm{SiO}_{2}, \mathrm{C} \equiv \mathrm{CaO}, \mathrm{T} \equiv \mathrm{TiO}_{2}$
\end{tabular}

and heating were used. The experimental design considered six independent variables: amount of water $\mathrm{X}_{1}$, mixing time $\mathrm{X}_{2}$, mixer rotational speed $\mathrm{X}_{3}$, vibration time $\mathrm{X}_{4}$, curing conditions $\mathrm{X}_{5}$, and the conditions of firing up to the working temperature $X_{6}$. The eight types of specimens were prepared under variable conditions defined at two levels, a lower level [-] and a higher level [+] relative to the reference value (Table 2), according to the experiment planning matrix for the orthogonal Plackett-Burman saturated design (Table 3). The value levels defined in the test, as shown in Table 2, correspond to the conditions prescribed by the manufacturer or by the standards (PN-EN 1927-5: 2013) [16], as well as the conditions that might occur during monolithic lining installation work not complying with the recommendations.

Table 3. Experimental design matrix (Plackett-Burman).

\begin{tabular}{cccccccc}
\hline \multirow{2}{*}{$\begin{array}{c}\text { Experiment } \\
i\end{array}$} & \multicolumn{7}{c}{ Factor (as per Table 2) } \\
\cline { 2 - 7 } & $\mathrm{X}_{0}$ & $\mathrm{X}_{1}$ & $\mathrm{X}_{2}$ & $\mathrm{X}_{3}$ & $\mathrm{X}_{4}$ & $\mathrm{X}_{5}$ & $\mathrm{X}_{6}$ \\
\hline 1 & + & + & - & - & + & + & + \\
2 & + & - & + & - & - & + & + \\
3 & + & + & - & + & - & - & + \\
4 & + & + & + & - & + & - & - \\
5 & + & + & + & + & - & + & - \\
6 & + & - & + & + & + & - & + \\
7 & + & - & - & + & + & + & - \\
8 & + & - & - & - & - & - & - \\
\hline
\end{tabular}

Testing methods

For each experiment the 3 samples $(230 \times 64 \times 64 \mathrm{~mm})$ were measured i.e. the total number of the tested samples was 24.

The determination of the apparent density and the open porosity was performed by the hydrostatic weighing method in accordance with PN-EN ISO 1927-6:2013 [17]. The bending strength at ambient temperature was determined in accordance with EN ISO 1927-6:2013 [17]. Three point bending test was conducted with a

Table 2. Values of levels of the investigated factors in the Plackett-Burman design.

\begin{tabular}{llcc}
\hline Factor $j$ & Factor $\left(\mathrm{X}_{j}\right)$ & Level $[-]$ & Level [+] \\
\hline 1 & Amount of water [\%] (distilled water) & 7.6 & 8.4 \\
\hline 2 & Mixing time [min] & 2 & 4 \\
\hline 3 & Mixer rotational speed [rpm] & 65 & 120 \\
\hline 4 & Vibration time [min] (for an amplitude of $0.5 \mathrm{~mm}$ ) & 3 & 5 \\
\hline 5 & Curing conditions $48 \mathrm{~h}$ in a mould and $24 \mathrm{~h}$ without & $20^{\circ} \mathrm{C}$, humidity $90 \%$ & $16^{\circ} \mathrm{C}$, humidity $60 \%$ \\
\hline & a mould (drying after curing at $110^{\circ} \mathrm{C}$ to constant mass) & & $10^{\circ} \mathrm{C} \cdot \mathrm{min}^{-1}$ to $350^{\circ} \mathrm{C}$, \\
$1 \mathrm{~h} \mathrm{dwell} \mathrm{time,}$ \\
$10^{\circ} \mathrm{C} \cdot \mathrm{min}^{-1}$ to $800^{\circ} \mathrm{C}$ \\
$2 \mathrm{~h} \mathrm{dwell} \mathrm{time}$
\end{tabular}


loading rate of $0.15 \mathrm{MPa} \cdot \mathrm{s}^{-1}$ and stress perpendicular to direction of fabrication was applied. The compressive strength determination was carried out in accordance with EN ISO 1927-6:2013 [17]. As a test pieces the broken halves produced from the three point bending test were used. To fulfill the requirements of EN ISO 1927-6:2013 a pressure perpendicular to the direction of casting with a loading rate of $1.0 \mathrm{MPa} \cdot \mathrm{s}^{-1}$ was applied. Young's modulus was determined using a dynamic method, where reso-nance vibrations were induced by impulse excitation using the Resonant Frequency and Damping Analyzer RFDA (IMCE/ Belgium) (ISO 12680-1:2005) [18]. The examination of permanent linear changes was performed in accordance with PN-EN ISO 1927-6 2013 [17].

\section{RESULTS AND DISCUSSION}

The examined system response functions providing a basis for the quality assessment of the produced castable were: apparent density, open porosity, permanent linear changes after firing at a temperature of $800^{\circ} \mathrm{C}$, as well as Young's modulus, compressive strength and bending strength at ambient temperature.

The average determination values, as summarized in Table 6, were obtained from three repetitions for each planned experiment

Based on the obtained results, the regression equation

$$
y=b_{0} x_{0}+b_{1} x_{1}+b_{2} x_{2}+\ldots+b_{\mathrm{k}} x_{\mathrm{k}}
$$

was determined, the individual factors of the regression equation being determined from the formula

$$
b_{j}=\frac{\sum_{i=1}^{N} x_{j i} y_{i}}{N},
$$

where $i$ is the experiment number, $j$ the factor number, $N$ the number of experiments, $x$ the variable value and $y$ the experimental result.

To verify the significance level of individual effects,
Student's t-test was used according to the formula

$$
t_{\text {calc }_{j}}=\frac{\left|b_{j}\right|}{s_{b_{j}}},
$$

where

$$
s_{b_{j}}=\frac{s_{r e p}}{\sqrt{N}},
$$

where $S_{\text {rep }}$ is the average standard deviation from all the determinations.

The regression equations obtained from the performed analysis of variance are summarized in Figures 1-6, where the significance level of individual factors, as expressed by $t_{\text {calc. }}$, are represented in graphical form. The significance test was performed based on Student's t-test. The critical value $t_{c r i t}=2.11$ was read out for the significance level of 0.05 and the number of degrees of freedom equal to 17 .

Figure 1 illustrates the effect of castable mix preparation conditions on the apparent density. Factors that significantly influence the material density are the amount of water $X_{1}$, the vibration time $X_{4}$, the curing conditions $\mathrm{X}_{5}$ and the conditions of firing up to the working temperature $\mathrm{X}_{6}$. Similarly as for the apparent density, the amount of water $\mathrm{X}_{1}$, strongly influences the open porosity of the examined castable, as illustrated by Figure 2. A further factor that strongly affects the properties of the material is the type of curing conditions $X_{5}$. The significance values of the factors $X_{3}$ and $X_{4}$ are close to the critical value determined from Student's t-distribution. Figure 3 illustrates the influence of castable mix preparation conditions on the permanent linear changes. Factors significantly influencing the permanent linear changes of the examined castable are the type of curing conditions $\mathrm{X}_{5}$ and the vibration time $\mathrm{X}_{4}$, while the remaining factors are below the critical value. As can be seen from Figure 4, the value of Young's modulus is strongly determined by the amount of water $\mathrm{X}_{1}$, the vibration time $\mathrm{X}_{4}$, and firing conditions $\mathrm{X}_{6}$. A significant factor in this case turns out to be also the mixer rotational

\begin{tabular}{|c|c|c|c|c|c|c|}
\hline Exp. & $\begin{array}{l}\text { Apparent } \\
\text { density } \\
{\left[\mathrm{g} \cdot \mathrm{cm}^{-3}\right]}\end{array}$ & $\begin{array}{c}\text { Open } \\
\text { porosity } \\
{[\%]}\end{array}$ & $\begin{array}{l}\text { Young's } \\
\text { modulus } \\
{[\mathrm{GPa}]}\end{array}$ & $\begin{array}{l}\text { Bending } \\
\text { strength } \\
{[\mathrm{MPa}]}\end{array}$ & $\begin{array}{l}\text { Compressive } \\
\text { strength } \\
{[\mathrm{MPa}]}\end{array}$ & $\begin{array}{c}\text { Permanent linear changes } \\
\text { after firing } \\
{[\%]}\end{array}$ \\
\hline 1 & $2.74 \pm 0.01$ & $22.3 \pm 0.4$ & $48.1 \pm 0.9$ & $15.0 \pm 2.6$ & $60.1 \pm 5.5$ & $0.19 \pm 0.10$ \\
\hline 2 & $2.77 \pm 0.00$ & $21.2 \pm 0.2$ & $53.2 \pm 3.9$ & $18.1 \pm 1.5$ & $66.6 \pm 4.0$ & $0.29 \pm 0.03$ \\
\hline 3 & $2.71 \pm 0.01$ & $23.2 \pm 0.2$ & $51.2 \pm 0.6$ & $15.8 \pm 1.7$ & $99.3 \pm 7.3$ & $0.17 \pm 0.16$ \\
\hline 4 & $2.71 \pm 0.01$ & $23.4 \pm 0.2$ & $42.8 \pm 1.3$ & $10.6 \pm 0.4$ & $85.1 \pm 1.4$ & $0.15 \pm 0.13$ \\
\hline 5 & $2.72 \pm 0.01$ & $22.4 \pm 0.2$ & $50.1 \pm 1.3$ & $15.1 \pm 0.7$ & $61.2 \pm 5.9$ & $0.31 \pm 0.04$ \\
\hline 6 & $2.78 \pm 0.01$ & $21.6 \pm 0.3$ & $54.5 \pm 2.0$ & $14.6 \pm 2.4$ & $103.2 \pm 5.0$ & $0.07 \pm 0.03$ \\
\hline 7 & $2.78 \pm 0.01$ & $20.8 \pm 0.5$ & $48.1 \pm 2.3$ & $12.7 \pm 0.7$ & $55.4 \pm 4.9$ & $0.17 \pm 0.08$ \\
\hline 8 & $2.75 \pm 0.01$ & $22.2 \pm 0.2$ & $52.4 \pm 1.2$ & $15.2 \pm 0.1$ & $109.0 \pm 3.8$ & $0.09 \pm 0.04$ \\
\hline
\end{tabular}
speed $\mathrm{X}_{3}$. The result of the performed analysis of the

Table 4. The results of apparent density, open porosity, permanent linear change, Young's modulus, bending strength and compressive strength determination. 
influence of the examined factors $\mathrm{X}_{1}-\mathrm{X}_{6}$ on bending strength at ambient temperature shows that it has been significantly influenced by two factors, namely the vibration time $\mathrm{X}_{4}$, and the firing conditions $\mathrm{X}_{6}$ (Figure 5). The factors $X_{1}$ and $X_{5}$ are situated practically at the significance borderline. A factor that definitely most heavily influences the compressive strength is the type of curing conditions $\mathrm{X}_{5}$. A slight, though statistically significant, effect has also been noted for the amount of water $\mathrm{X}_{1}$, the vibration time $\mathrm{X}_{4}$, and the firing conditions $\mathrm{X}_{6}$ (Figure 6).

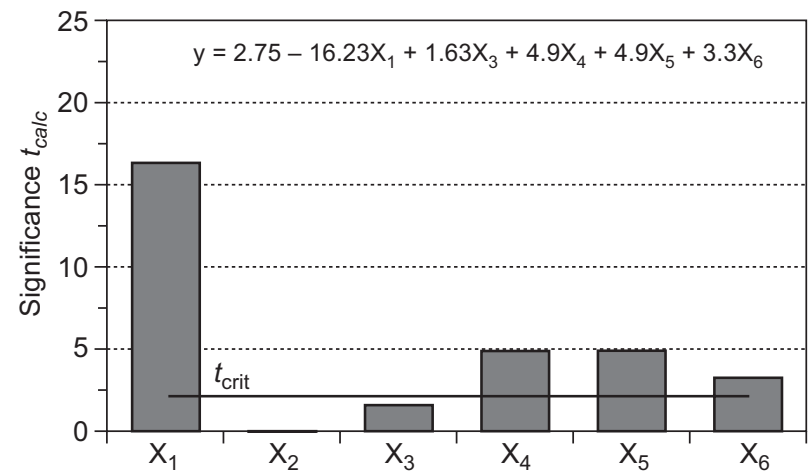

Figure 1. Factorial experiment results for apparent density with calculated regression equation.

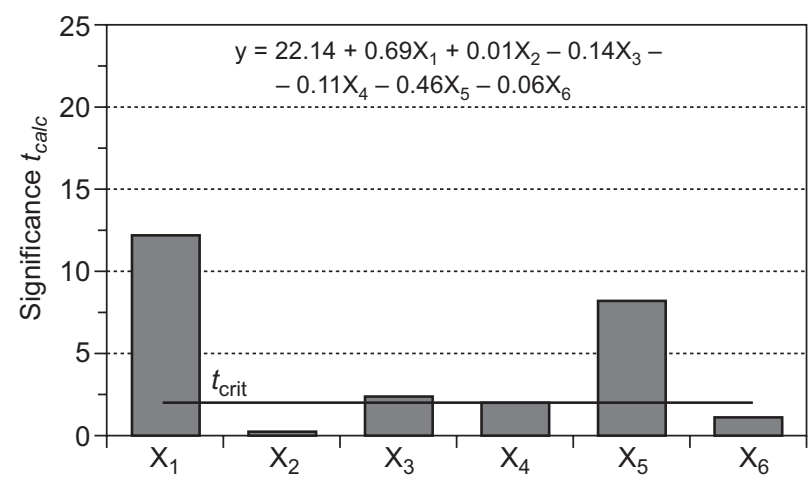

Figure 2. Factorial experiment results for open porosity with calculated regression equation.

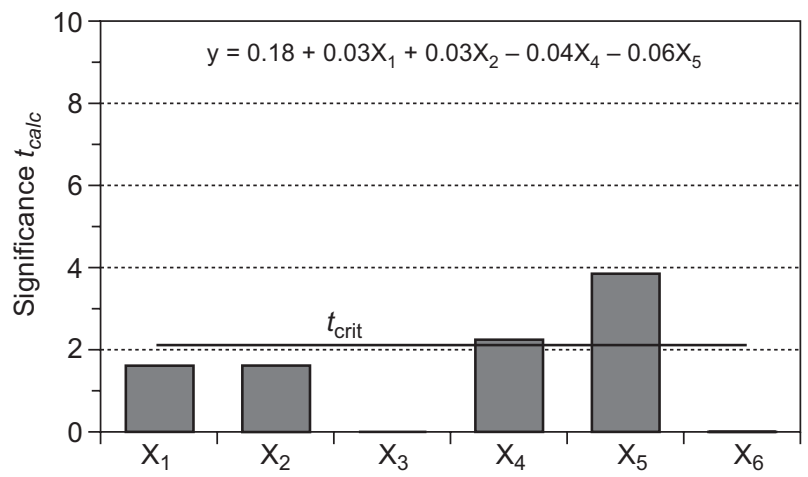

Figure 3. Factorial experiment results for permanent linear change with calculated regression equation.

\section{SUMMARY AND CONCLUSIONS}

Experiment planning methods have been used in this study for determining the relationship between the conditions of preparation, curing and heating of lowcement bauxite castable and its service properties.

Based on the obtained results, the significance of the following factors and their effect on the examined service properties has been established as follows:

- The amount of water is a factor that most significantly determines the apparent density, open porosity, Young's

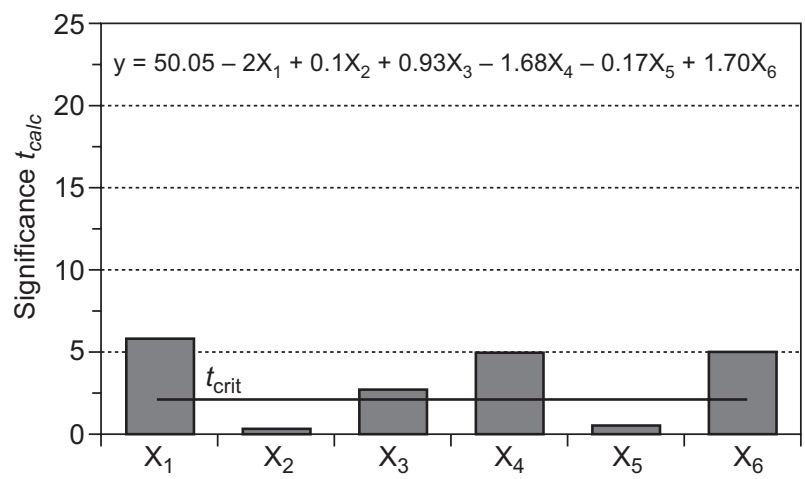

Figure 4. Factorial experiment results for Young's modulus with calculated regression equation.

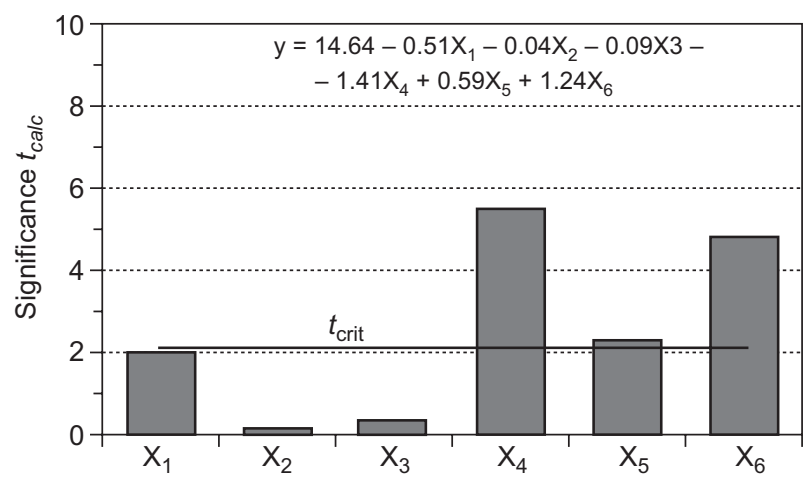

Figure 5. Factorial experiment results for bending strength with calculated regression equation.

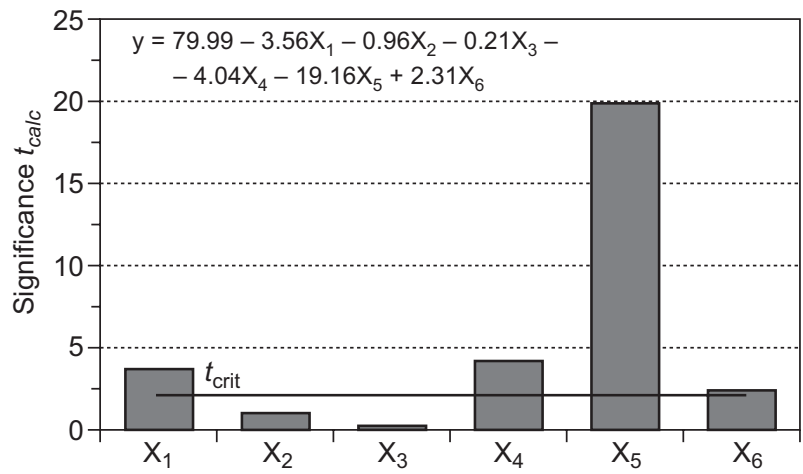

Figure 6. Factorial experiment results for compressive strength with calculated regression equation. 
modulus and, to a small extent, the compressive strength at ambient temperature.

- The mixer rotational speed influences the open porosity of the investigated castable; however, this influence, similarly as that of vibration time, was at the significance borderline, influencing mainly Young's modulus.

- The vibration time influences the apparent density of the material equally significantly as the curing conditions. It is a factor that most significantly determined the bending strength at ambient temperature.

The curing conditions influence significantly the apparent density and the open porosity; they are a key factor for the permanent linear changes and the compressive strength at ambient temperature.

- The conditions of firing up to the temperature of $800^{\circ} \mathrm{C}$ influences the apparent density, Young's modulus and the mechanical properties at ambient temperature.

The mixing time is the only of the examined factors, whose change within the examined range did not have any significant influence on the determined service properties of the investigated castable.

\section{Acknowledgements}

The study was supported by the Institute of Ceramics and Building Materials, the Refractory Materials Division in Gliwice.

\section{REFERENCES}

1. Lee W.E. Vieira W., Zhang S., Ghanbari Ahari K., Sarpoolaky H., Parr C. (2001): Castable refractory castables. International Materials Reviews, 46(3), 145-167. doi:10.1179/095066001101528439

2. Göğtaş C., Ünlü N., Odabaşi A., Sezer L., Güner Ş., Göller G., Eruslu M.N. (2012): Effects of firing temperature on the physical properties of a bauxite-based refractory castable. Refractories and Industrial Ceramics 53(1), 24-30. doi:10.1007/s11148-012-9455-9

3. Martinović S., Majstrović J., Vidojković V., VolkovHusovi T. (2009): Preparation and properties of low cement castable sintered at different temperatures. Processing and Application of Ceramics, 3(4), 191-196. doi:10.2298/ PAC0904191M

4. Altun İ.A. (2001): Effect of temperature on the mechanical properties of self-flowing low cement refractory con- crete. Cement and Concrete Research, 31, 1233-1237. doi:10.1016/S0008-8846(01)00533-6

5. Cardoso F.A. Innocentini M.D.M. Akiyoshi M.M. Pandolfelli V.C. (2004): Effect of curing time on the properties of CAC bonded refractory castables. Journal of the European Ceramic Society, 24, 2073-2078. doi:10.1016/ S0955-2219(03)00371-6

6. Fisher R.A. (1925). Statistical Methods for Reaserch Workers, Oliver and Boyd

7. Fisher R.A. (1935). The Design of Experiment. Oliver and Boyd

8. Rauf I.A. (2015): Applied Statistical Design of Experiments: Applications in Natural Sciences. Physical Chemistry and Biophysics, 5(5), 129-130. doi:10.4172/21610398. $1000 \mathrm{e} 129$

9. Montorsi M., Mugoni C., Passalacqua A., Annovi A., Marani F., Fossa L., Capitni R., Manfredini T., (2016): Improvement of color quality and reduction of defects in the ink jet-printing technology for ceramic tiles production: A Design of Experiments study. Ceramics International, 42(1), 1459-1469. doi:10.1016/j.ceramint.2015.09.091

10. Guzmán A.Á. Gordillo M.S. Delvasto A.S. Quereda V.M.F Sánchez V.E. (2016): Optimization of the technological properties of porcelain tile bodies containing rice straw ash using the design of experiments methodology. Ceramics International, 42 (14), 15383-15396. doi:10.1016/j.ceramint.2016.06.184

11. Coronado M., Segadães A.M. Andrés A., (2015): Using mixture design of experiments to assess the environmental impact of clay-based structural ceramics containing foundry wastes. Journal of Hazarous Materials, 299, 529-539. doi:10.1016/j.jhazmat.2015.07.010

12. Moreira M.H. Luz A.P. Cristoforo A.L. Parr C., Pandolfelli V.C. (2016): Design of Experiments (DOE) applied to high-alumina calcium aluminate cement-bonded castables. Ceramics International, 42, 17635-17641. doi:10.1016/j. ceramint.2016.08.079

13. Achnazarowa S.Ł. Kafarow W.W. (1982). Optymalizacja eksperymentu w chemii i technologii chemicznej. WNT.

14. Jańczewski D., Różycki C., Synoradzki L., (2013). Projektowanie procesów technologicznych. Matematyczne metody planowania eksperymentów. Oficyna Wydawnicza Politechniki Warszawskiej.

15. Plackett P., Burman J.P. (1946): The design of optimum multifactorial experiments, Biometrika, 37, 305-325.

16. EN ISO 1927-5: 2013 Monolithic (unshaped) refractory products - Part 5: Preparation and treatment of test pieces

17. EN ISO 1927-6: 2013 Monolithic (unshaped) refractory products - Part 6: Measurement of physical properties

18. ISO 12680-1: 2005 Methods of test for refractory products - Part 1: Determination of dynamic Young's modulus (MOE) by impulse excitation of vibration 